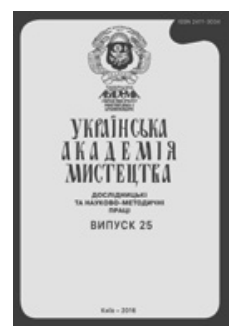

№27 (2018) стор. 221-226

The National Academy of Fine Arts and Architecture

Ukrainian Academy of Fine Art. Research and Methodology Papers

ISSN 2411-3034

Website: http://naoma-science.kiev.ua/

УДК 75.03:75.01:75.021:7.036«19/20»(510)=161.2

ORCID 0000-0002-0029-5983

DOI: https://doi.org/10.33838/naoma.27.2018.221-226

\author{
Sun Ke \\ postgraduate student at the \\ National Academy of Fine Arts and Architecture of Ukraine \\ Academic superviser O. Kovalchuk, Ph.D History of Arts \\ A.Q.H@hotmail.com
}

\title{
FIGURATIVE OIL PAINTING IN CHINA: FROM MAO TO NU
}

Summary. The range of problems of the influence of realistic art on the genre diversity in Chinese painting is revealed in the article. The processes caused by the cultural revolution and the following historical events in China are shown by the example of the formation of figurative painting during the twentieth century. A variant of the typology of Chinese figurative painting of the studied period is proposed based on the analysis of the most typical paintings.

Key words: China, oil painting, European influence, realism, figurative painting, painting genres.

\section{ФИГУРАТИВ В КИТАЙСКОЙ МАСЛЯНОЙ ЖИВОПИСИ: ОТ МАО К НЮ.}

Сунь Кэ

Аннотация. Раскрывается проблематика воздействий реалистического искусства на жанровое разнообразие в китайской живописи. На примере становления фигуратива на протяжении ХХ в. показаны проиессы, происходившие вследствие культурной револючии и дальнейших исторических событий в Китае. Предлагается вариант типологизации китайской фигуративной живописи тех времен; исследуется на знаковых примерах живописных работ.

Ключевые слова: Китай, масляная живопись, европейское влияние, реализм, фигуратив, жанры живописи.

\section{ФІГУРАТИВ У КИТАЙСЬКОМУ ОЛІЙНОМУ ЖИВОПИСІ: ВІД МАО ДО НЮ.}

Сунь Ке

Анотація. У статті розкривається проблематика впливів реалістичного мистецтва на жанрове розмаїття у китайському живописі. На прикладі становлення фігуративного живопису упродовж ХХ ст. показано процеси, що відбувалися після культурної револючії та подальших історичних періодів у Китаї. Визначено причини, ще вплинули на становлення фігуративного живопису загалом, та живопису ню зокрема. Також наголошено на суспільному сприйнятті нових стилів та його еволюиії.

Увагу акиентовано на стильових і символічних особливостях китайського фігуративного живопису окресленого періоду; досліджено еволючію зображення облич і постатей; роль $і$ значення червоного кольору в контексті традичійної китайської культури. Детально вивчено розвиток образів політичних лідерів, простого народу та героїчних персонажів. На прикладі кількох (знакових для свого часу) творів показано способи стилістичного протиставлення та водночас сюжетного об'єднання різних груп персонажів. Подано перелік та опис найхарактерніших сюжетів фігуративного живопису періоду культурної рево- 
лючї̈ та показано їхню роль у пропаганді, зокрема: зображення лідера, ілюстрачія героїзму, зображення червоної гвардії, зображення селян і солдатів. На основі дослідження стилістичних та сюжетних особливостей низки знакових живописних робіт запропоновано варіант типологізаиії та періодизаиії китайського фігуративного живопису того часу. Розглянуто основні прийоми та засоби вираження ідей художниками - від прямого використання транспарантів з текстом у картинах - до оригінальних композиційних та колористичних вирімень.

Виявлено досягнення та проблеми розглянутого жанру, а також поступове проникнення фігуративного живопису в суспільне життя Китаю. Оиінюється сучасний етап становлення фігуративного живопису в Китаї та його місие в сучасному глобальному культурному прочесі.

Ключові слова: Китай, олійний живопис, європейський вплив, реалізм, фігуратив, жанри живопису.

Formulation of the objective. The influence of European realistic art on Chinese oil painting during the cultural revolution period was of considerable value and importance. New genres also emerged and began to evolve then due to the introduction of new styles into Chinese art. To explore the figurative genre in Chinese art of that time, we have selected some famous artists whose creative lives and works, in our opinion, best represent the topic both due to their popularity and due to certain peculiarities, typical for contemporary artistic environment.

Analysis of recent research and publications. A number of researchers, among them Michael Sullivan, Zhou Shen Qui, Fan Dian, Lu Siaolu, Lin Fengmian and many others, who's works are cited below, were involved with the realm of China's realistic art, in particular in the genre of figurative art. However, there is a need to introduce the research of several most indicative and iconic artistic works of this genre into scientific circulation.

Main study. According to Zhou Shen Qui, figurative painting of this time can be divided into the following four categories ( $\mathrm{Lu}$ Siaolu 86).

1. Image of the Leader. Mao Zedong was the main character of the then painting. This can be seen in the Zhang Jin's «Mao on a Large-scale Production Site», and Chen Yanin's «Mao Zedong visited the rural areas of Guangdong» (1972).

2. Demonstration of heroism. Historical events were very important for the creativity of this period. The heroism of participants in those events became the basis for a large number of works, such as: «I Am a Petrel» by Pan Jiajzun (1971), «Pioneers» by Chen Yifei and Wei Jingshan (1972) etc.

3. Depiction of the Red Guard. The Red Guard consisted of young people and was considered the future of the country. These people were staunch defenders of the revolution. Examples include Chen Yanin's «The Diary of a Long March», «Work in fields» etc.

4. Portrayal of peasants and soldiers. During the late cultural revolution, the theme of peasants and soldiers became even more widespread, as it well conformed to the dogmas postulated by Mao Zedong. Let's recall, for example, the classic paintings «Autumn harvest» and «Spring breeze» by Zhou Shuqiao.

The works of the period of the cultural revolution can also be divided into the early and the late periods. There are a number of significant differences between them: during the late period (that is, the period of the cultural revolution), painting becomes closer to real life, it becomes saturated, filled with intense light. The emergence of specific themes, such as peasants and soldiers, studying students, farmers who are working, harvesting, etc., has become an expressive feature of that time painting. The demonstration of people's desire to unite for the sake of joint work, studying, building socialism became the main motive. The peculiarity of the figurative genre was that artists considered it necessary to embody and show the heroism and «correctness» of thinking in all the characters. The main character was always depicted as a most prominent one. Placed into the center of the composition, he seemed to be a main stage character or a monument. In the picture «Leader Mao accepts the Red Guard», young people from the Red Guard surrounded Mao who is in the car, welcoming him happily. Fluttering red flags in their hands, the Tiananmen Square as a background, accented difference in the size of ordinary people and Mao itself, all this reveals Mao has shown the highest honor to other characters in the picture and to the viewer as well. However, it also shows close unity of Mao and ordinary people, it shows people unite with each other around him.

We can see the same theme in the film «Team Fight», 
the main purpose of which was also propaganda. Here Mao is also located in the center, like a monument at the square, there is a crowd flowing and raging with a bunch of red flags and banners under him. This picture shows Mao's great leadership charisma, which must convince the viewer of correctness of the path chosen by China, while the background text shows the determination to fight capitalism and the desire to build a socialist society.

Artistic methods applied in these two paintings are identical, but the themes and ideas are different. Many characters in the «Leader Mao Receives the Red Guard» are shown in close-up, full face or in profile, which makes it possible to show positive faces and their internal psychological state, to fully utilize lighting, and thus to highlight the shapes of the characters with intense light. In the «Team Fight»»") we see the central image of Mao, surrounded by the ocean of people, which are shown very small and blend with each other against the background of banners and flags. It is not by chance that the banner of Mao, facing the viewer, repeats the main idea of the picture, as well as the text located in the upper left corner.

Cultural level of the people was low then, so the art was perceived by them not that well as in European countries. To give the broader public the opportunity to understand the party's policies some artistic means with strong propaganda effect were applied to painting. The goal was to attract the attention of people. Often a combination of text explanation and image was used. Li Yi's «Follow the leader Mao» and Shang Lian Xiao's «To be such a person» can be an example. In the picture «Follow the leader Mao» the image of Mao is still strong, but, unlike in the previous works of the artist, he looks not upward, but forward. This way of representing the hero, as wall as his smile, helps to make it closer to people. At the same time, we see that the picture is dominated by very strong wind, but Mao's figure is immutable as a stone, which fact is also used to emphasize the power of his revolutionary conviction.

Shang Lian Xiao's «To be such a person» (1971) is also a piece of propaganda art, which participated in the 1972 National Art Exhibition. During this period, the figures depicted in the paintings were strongly dramatized and looked very theatrical. For the most part, the characters fighting for the future were depicted. They were showing a high morale of people not afraid of difficulties. Here are some expressive examples: «Popular Revolutionary
Opera» by Hua Sonjing, «Innovation» by Tu Poxiun», To Serve People» by Liu Bozhong.

In the last painting, the flood obviously symbolizes the evil that is failing to fight against the heroes. The flood is extremely powerful, and the heroes must use all their forces to defeat it and turn it away. So, the main idea of the painting is the call to fight against evil. Executed in realistic style, this exaggeration means the ethical justification of a heroic struggle, combining the politics and life by the use of natural disaster as the most obvious metaphor.

Similar techniques were used in the «Copper Wall» painting by Zhang Dinini, «Mao Zedong visited the rural areas of Guangdong» by Chen Yanin, «Meet New Comrades» by Lee Bin, «Duty» by Ho De and Li Yangsheng, «Mao Inspects Coal Mines» by Yun Hua. The common point of these works is that Mao has become a life character who is depicted among people just as they are or a bit taller. In the painting «Mao Zedong visited the rural areas of Guangdong», the image of Mao becomes more meaningful, more humane. He stands among the people, what should show his love for the people.

So, we can distinguish and single out three major transformations in the subjects of figurative paintings of that period.

1. Initialy, the image of Mao was much divinized, in later paintings it became closer to people, to the true life.

2. Initially, Mao's image was portrayed looking upward, aimed solely at the ideal, later Mao began to look straight forward.

3. Initially, the artists sought only to glorify the characters, but later more romantic feelings and freedom have arisen.

The ideas and themes were common within figurative painting, as they remained unchanged despite the change in artistic language, methods and techniques. Also common was the realistic style and the color palette dominated with red vivid colors, which is clearly obvious in almost every work. The light in the paintings had a red hue, with the help of which the artists made the colors more vivid, as, for example, in the «Armed workers have ambition»».

So why was the red color used?

1. Red color has a deeply rooted historical meaning in the concept of Chinese cultural tradition. Festivals, weddings are all decorated in red, people believe the 
red is a symbol of happiness.

2. In Buddhist religion, in Buddhist art, the red color has prevailed since ancient times, many artists used it as the main one.

3. According to Kandinsky, the red color is unlimited. Its nature is warm, its symbolism is fierce, and this combination is just right to express the Chinese way of thinking. However, European artists often use red as one of the most expressive colors as well.

4. And, of course, red color is a symbol of then political system in China.

Chen Kai's «The workers and peasants are singing red songs» is revealing in this sense. It shows joy after harvesting. Almost all the details in this painting are based on the red color. We see the same in the «We met Mao» painting, where even the general hue is red. The red color does not symbolize life, blood that much, as it has a strong influence on the viewer's mind, it instantly attracts their attention. This color is ideally suited for propaganda and advertising.

In later periods artists began to use less red, instead they painted with more natural colors. This peculiarity in the formation of painting can be traced in the picture by Shen Davei «Eat Snow», which depicts all the same workers, usual characters of figurative painting, after work, having a break under the sun. But it is build around the reflective surface, the composition already does not comply with previously formed standards, the mandatory red flags are no longer there, instead there is only a tree and warm light, as a symbol of harmony and happiness. The same is seen in the painting of $\mathrm{He}$ Shaodiao «Learning for Perfection» and Shang Ding's «Continuous Struggle».

Gray color and cold tints also occupy the leading places in the works of this period. For example, in Tang Xiaomin's «Never stop struggle» of 1972, which depicts a famous writer Lu Xiun. There are no bright colors, but the artist was able to show the hardness of the character of a person who strives to achieve a goal.

Facial expression of the characters in paintings of that time has also had its own peculiarities. More free facial expressions were typical for the portraits of later periods (Sullivan 206-214). It was not so much artistic exaggerations as vitality, the inner world of a person what mattered, such as in the paintings of Yang Zhiguan «Miners» and the «Young Doctor» by Chen Yanin. The «Miners» painting was completed in 1972 and is now kept in the Museum of Chinese Art. This work very accurately shows the amalgamation of Chinese painting and drawing with European realism, as the miner's figure is almost alive.

Chinese figurative painting of that period is also notable for optimistic faces with positive facial expressions, often on the brink of passion. Let us recall Zhao Chigitan's «Greetings to the Shanghai Revolutionary Committee» and «The Daqing Workers» as examples. Therefore, optimistic and positive facial expressions that symbolize kindness and indestructible, boundless vitality are often accompanied by seriousness, concentration, and inner strength, as in Tang Zhihuan's «Mao».

So, after studying the most striking features of figurative painting, we can assume that during the whole of the twentieth century it was dominated by a realistic style, combined with artistic peculiarities of the tasks posed to the artists. In later periods, when the cultural dictate of the state power became less noticeable, artists began to return to their inner feelings, emotions. To reveal them they turned to traditional Chinese painting and drawing, to European realism. They also used other styles and techniques to fulfill their creative tasks.

One of the most interesting and controversial types of figurative art in Chinese art is $\mathrm{Nu}$ painting. Introduction of $\mathrm{Nu}$ painting into the Chinese artistic process (and its subsequent formation) is of a great importance for understanding contemporary transformations in Chinese oil painting. In this article we will explore the most prominent creative works of artists who depicted nude figures.

There was a possibility to draw a nude female model in the Shanghai Academy of Art already since July 1920. But the first model in Chinese painting history had to leave the job in a few days under the pressure of her own family. Such artists as Chen Bao I, Van Yue Jie, Li Shutung also worked in the genre of $\mathrm{Nu}$. In this aspect of even more interest is the fact, that they were portraying their wives. These two points indicate the willingness of the then Chinese society to unconditionally accept the $\mathrm{Nu}$ painting as a full-fledged part of fine arts.

Another point is that due to the dramatic political and social conflicts in China in the period from the beginning of the XXth century to 1949 Chinese society was not interested in culture and fine arts. The circle of amateurs and enthusiasts of new European art was confined 
to large well developed industrial cities such as Shanghai and Beijing. Therefore, the artists, who practiced the genre of $\mathrm{Nu}$, just empirically stylized their work in accordance with contemporary trends. The use of naked nature in fine arts was banned in 1949. A strict state censorship was introduced. The work of artists in this field has completely changed, since the depiction of the naked figure was allowed for educational needs only.

Given the political transformation in China, Deng Xiaoping demanded to free thinking from the old stereotypes (Fan Dian, Leng Lin, and Hans van Dijk 5). Thus, when designing interiors of the international airport in Beijing in December 1977, it was decided to decorate them with paintings by contemporary artists, what the masters from the Central Academy of Decorative Arts (now - the Institute of Fine Arts of the University of Qinhua) were invited for. The work lasted from 1977 to 1979 .

In March 1979, the government rehabilitated many artists who were oppressed during the Cultural Revolution. This event has become very important for contemporaries, in connection with gaining more creative freedom and awareness that it was possible to develop artistic ideas and genres that were banned hitherto.

Yuan Yong Shen has created «The Festival of Songkran» fresco for the airport (Figure 1). It shows the tradition of festive fun when people pour water on each other, some naked figures were shown in the picture. The «The Festival of Songkran» composition was not a self-sufficient work, rather a part of monumental ensemble of paintings. It was $27 \mathrm{~m}$ long and 3, $4 \mathrm{~m}$ high linen canvas glued to the wall.

The plot of the picture is a festival of Thai nationality. Despite Deng Xiaoping praised this work, the airport administration decided to change at its own discretion those fragments where the naked women had been shown. The nude bodies were covered with white silk. This comical case is quite similar to when Michelangelo's frescoes in the Sistine Chapel were repainted to cover certain parts of the figures. To avoid an even bigger scandal, the airport authority decided to close these pieces of painting with special screens. Art critic Ma Hongzen spoke about the fact that Chinese artists, when interpreting European influences in their art, should pay more attention to Chinese traditions and be more tactful. Therefore, he considered exhibit of painting with naked figures in the public space untimely and inappropriate, even more inappropriate in such important monumental works.

Chinese artist $\mathrm{Wu}$ Guan Jun, believed that the $\mathrm{Nu}$ genre should be gradually popularized in Chinese society. At that time there was an active social discussion about the need for a nude figure images, inspired by the story of the above monumental painting at the Beijing airport. This piece of art is still not accessible to a wide audience, because a cafe was built in that area of the terminal. A famous artist and art critic Wu Weishan believes that the work of Yuan Yun Sheng, its artistic language, is very important both for understanding the history of Chinese monumental art and for the development of new art, so it is necessary to create a museum of this fresco.

In the sixth issue of the «Art» scientific magazine in 1980, 16 articles on nudity in fine arts were published, and in the 12th issue of the same year there were 4 more such articles (Lyu Vej 10). In general, in the year 1980, the total of 23 articles on this subject were published in this single magazine. Six of those publications negatively responded to the work of Chinese artists in this genre; instead, eight articles positively assessed them, while nine authors took a neutral position. Analyzing this, we conclude that only people who were far from the fine arts opposed the $\mathrm{Nu}$ trend. Professional artists and art critics have supported the introduction of European traditions into Chinese fine arts in general. So, only in 1980, during the beginning of the reforms of openness, the public opinion in China on the $\mathrm{Nu}$ painting has been encouraged to radical changes. Tan Dae Xi created a sculptural work «Heroics» in Guangzhou City in 1978, which depicted a naked archer girl on a prancing horse. This work is one of the first works available to the general public, where the beauty of the naked figure is celebrated.

More and more artistic educational institutions began to open permanent model positions during this period. The Academy of Theater in Shanghai also announced a competition for a model position at the theater and decorative art faculty in 1985. There were countrypeople among the applicants of the competitions, which previously would have been impossible at all. This clearly illustrates the gradual change and softening of patriarchal customs, which began to give way to modern trends.

In the book «The theory of naked figure depiction» (1987) the artist and art critic Chen Zhuei, for the first 
time in China, raised the question of working with a model on a high professional level. From December 22, 1988 to January 8, 1989, an exhibition was held at the National Museum of Art of China, where works of oil painting in the genre of $\mathrm{Nu}$ were presented. According to available data, this vernissage was attended by more than 200 thousand people. The exhibition featured works of more than two dozen young teachers of the oil painting department of the Central Academy of Arts. Also, several authoritative and competent professors were invited to participate in the exhibition. Among them were Din Shan I, Chang Cien Chun. This was the first $\mathrm{Nu}$ exhibition held at such a high level. Prior to this similar exhibitions took place in some other cities, but only in private galleries where the works of lesser-known artists were exhibited. Beside that, some selected works of European classical art devoted to the depiction of the naked figures began to appear in periodicals.

Conclusions. So, we can assert that Chinese oil painting has gone a long way from the traditional painting of guohua, xieyi, etc., to the modern one during the twentieth century, which has been happening first under the influence of European art, then socialist realism of the USSR, and later, at the end of the century, under the influence of the global art trends. The genre diversity was significantly limited in its development for most of the century, which is still a problem.

While in the global artistic culture the introduction of the nude painting has long been a passed stage, and the corresponding genres have experienced a long history of development, in the Chinese arts these processes are still passing some critical points of the establishment.

\section{References}

1. Fan, Dian. Chinese Fine Arts in the 1990's. [S. L.]. 1993. Print.

2. Fan, Dian, Leng Lin, and Hans van Dijk. Ideals and Idols of Beijing (catalog).

Hong Kong: Schoeni Art Gallery, 1994. Print.

3. Fan, Dian. Ten Noted Contemporary Chinese Oil Painters and Their Artistry.

Fuzhou: Fujian Fine Arts Press, 1994. Print.

4. Lu, Siaolu. «Everybody have their own way: in memory of the pioneers of modern

Chinese art, who studied in East Asia and in the West». Art and Asia Pacific (2004): 86. Print.

5. «中国油画史》刘淳著, 中国青年出版社, 2005年7月 462页 [Лю Чун. Історія китайського олійного живопису. Пекін: Кит. молодіж. видав. дім. 2005].

6. 《满幅韵律总关情一马常利先生的油画艺术》 范迪安 发表于 《中国文化报》2015年12月13日

URL:http://wap.cnki.net/baozhi-CWHB $\neg 2015 \neg 1213 \neg 00 \neg 81 . h t m l$ (Дата звернення: 13.12.2015). [Фань Діан. «Олійний живопис Ма Чан Лі». Новини китайської культури. Веб. 13 Груд. 2015. < http://wap.cnki.net/ baozhi-CWHB $\neg 2015 \neg 1213 \neg 00 \neg 81 . h t m l>]$.

7. Sullivan, Michael. Art and Artists of Twentieth-Century. China. Berkeley. Los

Angeles: Ahmanson Murphy Imprint in Fine Arts, 1996. Print.

Подано до редакиії 24.12.2018

Рецензенти:

Стасенко В. В. - кандидат мистецтвознавства, професор;

Ковальчук О. В. - кандидат мистецтвознавства, доцент. 